\title{
Ethnoecology: The traditional landscape of Osing Tribe in Banyuwangi, Indonesia
}

\author{
BUDI PRASETYO ${ }^{1,2, \bullet}$, TATIK CHIKMAWATI ${ }^{3}$, EKO BAROTO WALUJO $^{1}$, ERVIZAL AMZU $^{4}$ \\ ${ }^{1}$ Plant Biology Program, Department of Biology, Faculty of Mathematics and Natural Sciences, Institut Pertanian Bogor. Jl. Raya Dramaga, Bogor \\ 16680, West Java, Indonesia. Tel.: +62-251-8622833, `email: budijabon@yahoo.co.id \\ ${ }^{2}$ Biology Study Program, Department of Biology, Faculty of Mathematics and Natural Sciences, Universitas Terbuka. J1. Cabe Raya, Pondok Cabe, \\ Pamulang, Tangerang Selatan 15418, Banten, Indonesia. \\ ${ }^{3}$ Department of Biology, Faculty of Mathematics and Natural Sciences, Institut Pertanian Bogor. Jl. Raya Dramaga, Bogor 16680, West Java, Indonesia \\ ${ }^{4}$ Department of Forest Resources Conservation, Faculty of Forestry, Institut Pertanian Bogor. Jl. Raya Dramaga, Bogor 16680, West Java, Indonesia
}

Manuscript received: 16 July 2018. Revision accepted: 16 October 2018.

\begin{abstract}
Prasetyo B, Chikmawati T, Walujo EB, Amzu E. 2018. Ethnoecology: The traditional landscape of Osing Tribe in Banyuwangi, Indonesia. Biodiversitas 19: 2003-2009. There is a concern that the decreasing area of Osing tribe in Banyuwangi may cause the decline of the farming culture that has been rooted in their daily lives. This research aimed to analyze the traditional knowledge of Osing tribe in the management and utilization of landscape units generated from farming activities and the benefit assessment of landscape units based on gender perception. The research used explorative method with emic and ethic approaches. The importance of each landscape element is assessed through MLA (Multidisciplinary Landscape Assessment) by scoring with Pebble Distribution Method (PDM) in Focus Group Discussion (FGD). The respondents consisted of females and males with three age categories: 11-17 years, 18-45 years, and $\geq 46$ years. The results of PDM showed that the Osing tribes in the three villages of study sites considered their yards as the most important landscape unit in their lives (PDM $=42.82)$, followed by paddy field $(\mathrm{PDM}=26.05)$, garden (PDM = 16.12), and finally field (PDM = 15.01). Based on gender perception, a house with a yard had higher importance (PDM $=45.09)$ in female's perception than in male's $(\mathrm{PDM}=40.55)$. Three canopy strata or layerswere found in village landscapes, namely yard, paddy field, garden, and field.
\end{abstract}

Keywords: Age, emic and ethic, gender, PDM, FGD

\section{INTRODUCTION}

The word landscape in the geographical context has a comprehensive meaning and utmost importance because the formation of a region both physically and socially involves many integrated components including community, justice, law, economy, and politics (Olwig 1996). Due to the complexity and integration of the components, landscape can be interpreted as an environmental unit which is a concept of holistic and common space, much broader than the sum of its constituents (Sheil et al. 2002). Physically, the manifestation of the complexity of the relationship can be composed of plain, soil, vegetation and land use, or in fact landscape unit is considered as a cultural framework.

The complexity and integration of the environmental components are recently considered as the basis of ethnoecology in analyzing cultural framework of traditional society on various spatial patterns of landscape unit or ecosystem as the result of interaction with the environment. The reality and realization of the cultural framework also exist in Osing tribe in Banyuwangi, in the easternmost of East Java Province. The existence of the landscape units assembled in a rural landscapeis the result of interaction between the community and natural environment.

The Banyuwangi District is famous for its granary due to its fertile soil; therefore, the indigenous people of the
Osing tribe live prosperously. The people of Osing tribe are believed to be the descendants of the Blambangan kingdom troops who are also famous as competent and tough farmers (Sutarto 2006). Previously, the distribution area of Osing tribe included 24 sub-districts, but now it decreases to 9 sub-districts (Sutarto 2006). The reduction of Osing tribe area is assumed to decrease the traditional value of farming which is rooted in their lives. In the environmental management, men and women naturally have different experiences in dealing with their problems, and as a result they will produce different knowledge and make different decisions, especially in handling a landscape unit with its biodiversity components.

In the rapid growth of science and technology nowadays, Osing tribe community still keeps the custom and tradition built hundreds of years ago. Each landscape unit managed by Osing tribe community are multifunction ecosystems, the association of these landscape units illustrates the rural landscape, an important platform for integrating biological and cultural diversity for human welfare (Agnoletti and Rotherham 2015). Therefore, the eological study of village landscapes is expected to be the basic reference in understanding the related aspects in detail that is associated with the natural resources and biodiversity (Raynor and Kostka 2003). The aims of this study were to analyze the traditional knowledge of Osing community in managing and utilizing landscape units or 
ecosystem generated from farming activities, and analyzing the beneficial value of each landscape unit based on gender perception.

\section{MATERIALS AND METHODS}

The research was conducted in November 2015 to December 2016 in the villages of Kemiren and Taman Suruh of Glagah Sub-district, and Jambe Sari village of Giri Sub-district, Banyuwangi District, East Java Province, Indonesia (Figure 1). The main criteria for the selection of research locations were: (1) most of the villagers belong to Osing tribe, and (2) there are many traditional and village elders who understand the history of Osing tribe. Kemiren village represented a village which still upholds and consistently performs various rituals and customs inherited from their ancestors, while Taman Suruh and Jambe Sari villages represented villages which rarely perform rituals and customs.

The research used an explorative method based on the emic and ethic approaches. Through the system of knowledge and cognition, the knowledge which is conceptual, categorical, coded, and cognitive rules (emic) of the society was proved through the principle of science which is gained from scientific background (ethic) (Rosa and Orey 2012). The importance of each landscape element was collected and assessed using MLA (Multidisciplinary Landscape Assessment) (Boissiere et al. 2007) by scoring exercise using the Pebble Distribution Method (PDM) on the Focus Group Discussion (FGD) (Sheil et al. 2002). The
PDM data were collected from 10 key informants and 396 respondents, consisting of females and males (Vodouhe et al. 2010; White Jr. et al. 2011) with three age categories i.e. $11-17,18-45$, and $\geq 46$ years old (Dolisha et al. 2007; Guthiga 2008; Schaich 2009). The selection of key informants was based on the snowball sampling technique, while the respondents were selected based on the purposive sampling technique (Neuman 2003). The vegetation analysis was conducted by measuring directly every area of a landscape unit which was used as a research plot by referring to the area size in tax letter (SPPT 2015). The measured parameters were density, frequency, and dominance of plant species, and Importance Value Index (IVI), determined by calculating the relative density and relative dominance (Cox 2002).

\section{RESULTS AND DISCUSSION}

\section{The general perception of Osing community towards environment}

The environment for Osing community is a unity that is closely related to their daily lives, because it provides an area to settle and do all social and cultural activities, and productive land in relation to economic business of its owner. The result of interaction between Osing community and the environment through farming activities is manifested in four kinds of landscape units namely yard, paddy field, garden, and field. However, the community also generates cemetery landscape unit as complement of their needs of life cycle.
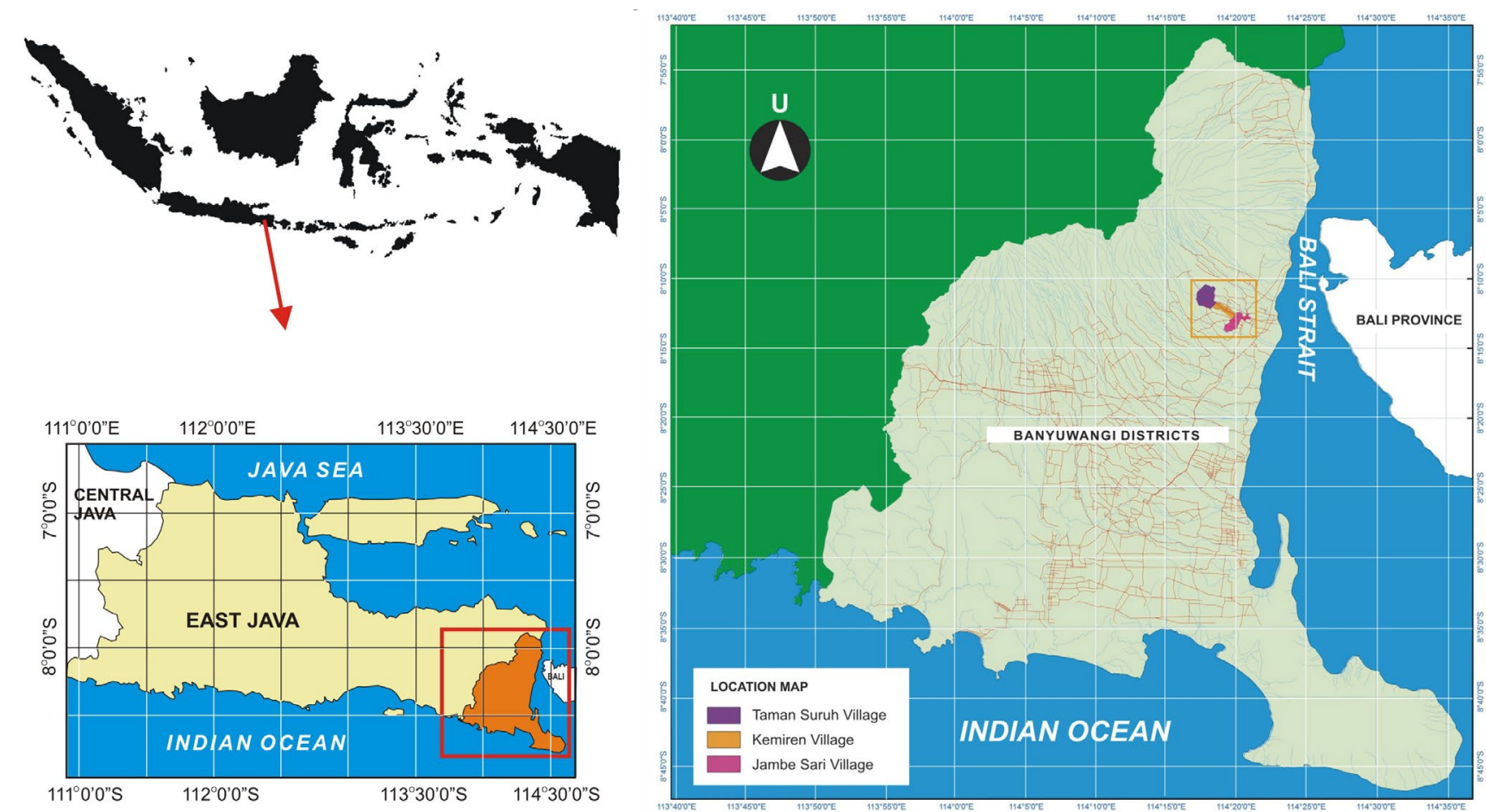

Figure 1. The location map of the study area in Banyuwangi District (Bakosutarnal 2006) 
The assessment result using the PDM on all landscape units around Osing community is presented in Figure 2. In general Osing community in Kemiren, Taman Suruh, and Jambe Sari villages stated that their yards were the most important landscape unit in their lives followed by paddy field, garden, and field.

The PDM score of yard landscape unit was the highest because the community has a perception that they may plant various plant species such as vegetables, herbs, fruit trees, ornamental plants, and medicinal plants in their yard easily. By planting many plant species, they hope that they are able to suffice the nutrient of their families, save expenses, and increase their income (Garrity 2004). The Osing tribe realizes that even though they are good in farming, the agricultural production cannot be their major income for supporting their daily lives, so,the paddy field landscape is their second choice for increasing their income (Figure 2).

Osing tribe community, both males and females, considers yard, paddy field, garden, and field as landscape units that function as supporting resources of their life. The result of PDM valuation on the importance of each landscape unit (Table 1) shows that in the yard landscape fruits had the highest PDM value, followed by ornamental plants, vegetables and herbs, and medicinal plants. The high score of fruit is reasonable since fruits have the second highest contribution to the income after paddy. Several fruit species that give an additional income for the community are two banana cultivars (pisang lempeneng and pisang sobo), durian, coconut, langsat, jackfruit, mango, and mangosteen. Pisang lempeneng is a favorite banana grown by Osing society in Glagah Sub-district, Banyuwangi District (Hapsari et al. 2015). Ornamental plants had the second highest PDM value after fruits. It indicates that Osing tribe has strong beauty flavor towards ornamental plants; therefore, they grow them in their yards. They use vegetables, herbs, and medicinal plants mostly for cuisine and medicines for some diseases (Rao et al. 2004).

The PDM value of paddy in paddy field was very high $(\mathrm{PDM}=53)$, followed by that of construction material $(\mathrm{PDM}=11.9)$, while the score of other plant species was relatively low. Paddy as main food source for Osing community becomes an asset that has high value, thus, it becomes irreplaceable species, and cannot be substituted by other species such as corn, cassava, yam, and lesser yam. Coconut trees are widely cultivated in paddy bunds by Osing community especially the bunds closed to the garden. A small part of the community use the coconut trunks for construction materials such as rafter, batten, door post, and window post (Table 1).

Garden and field become the highest landscape choice for Osing community to get fruits, as indicated by the PDM value of fruits in both landscapes which was higher than the others'. Fruits contribute the biggest income to each family in Osing community. Durian, coconut, banana, and mangosteen often become the main fruits to support their economy since they sell all the fruits to the fruit collectors and also in traditional markets.

In their social life, Osing tribe cannot be separated from their daily needs, their secondary needs, i.e. the needs of alternative staple food, medicine, fire wood, and materials for rituals and custom. All materials to fulfill the secondary needs are spread in four landscape units. They are not primary needs but should be fulfilled and their availability should be sustained. The existence of the landscapes is very important in the three villages and expected to be maintained so that the areas will not decrease or switch functions (Dale et al. 2000; Fischer et al. 2012), so villages indirectly become the source of natural

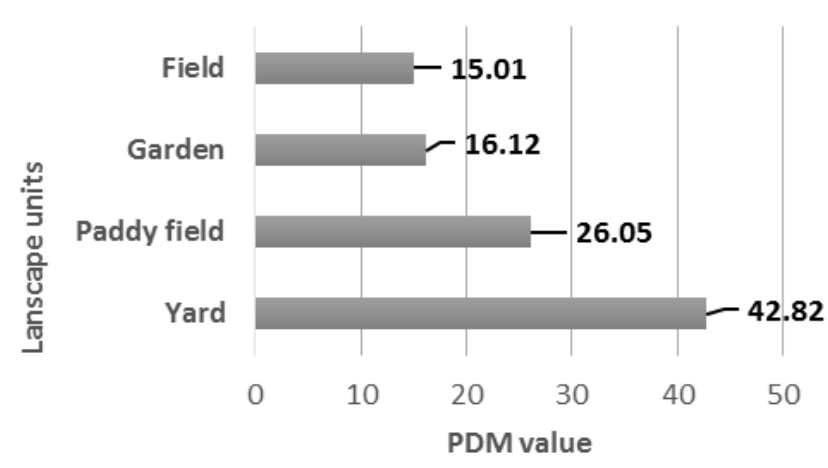

Figure 2. Result of PDM assessment on benefits of landscape units by all Osing tribe society

Table 1. The results of PDM assessment on landscape units as the source of needs based on gender perspective

\begin{tabular}{|c|c|c|c|c|c|c|c|c|}
\hline \multirow{3}{*}{ Source of need } & \multicolumn{8}{|c|}{ Landscape unit } \\
\hline & \multicolumn{2}{|c|}{ Yard } & \multicolumn{2}{|c|}{ Paddy field } & \multicolumn{2}{|c|}{ Garden } & \multicolumn{2}{|c|}{ Field } \\
\hline & $\mathbf{M}$ & $\mathbf{F}$ & $\mathbf{M}$ & $\mathbf{F}$ & $\mathbf{M}$ & $\mathbf{F}$ & $\mathbf{M}$ & $\mathbf{F}$ \\
\hline Staple food & 10.26 & 10.01 & 56.11 & 50.08 & 11.20 & 7.81 & 14.84 & 12.70 \\
\hline Fruits & 37.23 & 32.86 & 8.12 & 10.81 & 40.44 & 39.55 & 34.82 & 36.38 \\
\hline Vegetables \& herbs & 13.00 & 16.90 & 6.83 & 8.63 & 8.12 & 9.19 & 15.28 & 14.59 \\
\hline Ornamental plants & 17.69 & 17.42 & 2.16 & 3.08 & 4.54 & 4.80 & 6.86 & 5.96 \\
\hline Medicinal & 7.24 & 7.27 & 3.87 & 3.72 & 5.55 & 5.32 & 5.87 & 6.61 \\
\hline Fire wood & 5.12 & 5.42 & 6.73 & 6.10 & 8.35 & 9.35 & 7.67 & 8.18 \\
\hline Building construction & 6.13 & 5.72 & 11.86 & 11.99 & 17.28 & 18.77 & 10.22 & 10.35 \\
\hline Custom ritual & 3.33 & 4.40 & 4.32 & 5.61 & 4.50 & 5.22 & 4.44 & 5.23 \\
\hline Total & 100.00 & 100.00 & 100.00 & 100.00 & 100.00 & 100.00 & 100.00 & 100.00 \\
\hline
\end{tabular}

Note: M: Male F: Female 
resource, to strengthen the existing food security. The integration of house and plants in each landscape unit makes the complexity of social economy, cultural, and ecological functions (Farina 2000; Garrity 2004). Social economy and cultural functions are shown in planted species and their benefit while ecological function is the results of the structure and composition of plant community in each landscape unit.

Referring to ecosystem concept, the description of plant community structure found in each landscape unit shows the species composition and their abundance. Four vegetation analyses of all landscape units in the three villages were conducted and the results are presented in Tables 2-5. Table 2 shows that pisang lempeneng, pisang ketip, rambutan, and rose apple are the fruit species having high importance value in yard. Four fruit species are intentionally planted for three reasons i.e. the convenience in cultivating, the delicious taste, and the high economic value. Bananas have many benefits (Hapsari et al. 2015) and Osing community often uses banana for ritual and custom activities. Its leaves and fruit are used in ceremonies for renovating and building a house, and birth (Kennedy 2009).

Paddy landscape is the main source of staple food, i.e. paddy (Oryza sativa) and had higher IVI than the other species (Table 3). It shows that paddy is abundant and evenly distributed in three villages.

Those data also give information that farmers are dependent on their agricultural products, and they are competent in the correct farming technique by giving priority to natural materials to fertilize their paddy fields, but they also use synthetic fertilizers. Farmers from Kemiren village are famous among Banyuwangi community for their expertise in farming, and their expertise is often used by neighboring villagers.

Table 4 gives information on plant species that dominated the garden landscape in the three villages. Coconut (Cocos nucifera) and durian (Durio zibethinus) were the species which had high value and were evenly distributed in the garden of Osing community. It is believed that both species contribute to fulfill the daily needs; therefore, the community maintains the species better than others.

Pisang sobo (Musa x paradisiaca triploid ABB) had high IVI value in Kemiren and Taman Suruh villages, while in Jambe Sari village it had relatively low IVI. Bambu benel (Gigantochloa atter) also had high IVI value in Kemiren dan Jambe Sari villages, but in Taman Suruh village it had low value. Referring to the benefits of both species, they had high value in their group because pisang sobo is delicious and bambu benel has high quality, i.e., high durability, to be used as building construction material. Their low IVI in the other two villages triggered curiosity regarding Jambe Sari and Taman Suruh community's perception towards cultivation of both plant species. Several garden owners mentioned that they intentionally planted bamboo species including bambu benel in order to protect their landscape against landslide caused by rainfall (Gadgil et al. 1993; Tardio et al. 2017).

Table 2. Plant species with the highest Importance Value Index (IVI) in the yard landscape of the three villages

\begin{tabular}{|c|c|c|c|c|}
\hline Local name & Scientific name & $\frac{\text { Kemiren }}{\text { IVI }}$ & $\begin{array}{c}\text { Taman Suruh } \\
\text { IVI }\end{array}$ & $\frac{\text { Jambe Sari }}{\text { IVI }}$ \\
\hline Pisang lempeneng & Musa $x$ paradisiaca triploid AAB & 6.59 & 5.52 & 5.33 \\
\hline Pisang ketip & Musa acuminata & 5.64 & 4.31 & 4.94 \\
\hline Rambutan & Nephelium lappaceum & 5.26 & 5.12 & 6.06 \\
\hline Jambu air & Syzygium aqueum & 5.07 & 4.17 & 4.75 \\
\hline Bunga sore & Mirabillis jalapa & 4.90 & 3.09 & 4.56 \\
\hline Katuk & Aalius androgyna & 4.50 & 3.77 & 2.73 \\
\hline Mangga & Mangifera indica & 4.89 & 3.68 & 4.56 \\
\hline
\end{tabular}

Table 3. Plant species with the highest IVI in the landscapes of the three villages

\begin{tabular}{|c|c|c|c|c|}
\hline \multirow{2}{*}{ Local name } & \multirow{2}{*}{ Scientific name } & \multirow{2}{*}{$\begin{array}{c}\text { Kemiren } \\
\text { IVI }\end{array}$} & \multirow{2}{*}{$\begin{array}{c}\text { Taman Suruh } \\
\text { IVI }\end{array}$} & \multirow{2}{*}{$\frac{\text { Jambe Sari }}{\text { IVI }}$} \\
\hline & & & & \\
\hline Padi & Oryza sativa & 108.90 & 108.28 & 109.03 \\
\hline Gundo & Cleome rutidosperma & 9.10 & 8.34 & 9.09 \\
\hline Kelapa & Cocos nucifera & 9.10 & 8.34 & 9.09 \\
\hline Pisang sobo & Musa x paradisiaca triploid BBB & 9.09 & 8.33 & 9.09 \\
\hline Pisang ketip & Musa acuminata & 9.09 & 6.95 & 6.06 \\
\hline Rumput teki & Cyperus rotundus & 7.58 & 8.33 & 6.06 \\
\hline Pisang lempeneng & Musa $x$ paradisiaca triploid AAB & 4.55 & 8.33 & 9.09 \\
\hline
\end{tabular}


Table 5 gives information that pisang sobo had high IVI value in field in the three villages, and the value was even higher in Jambe Sari village. The condition shows that the community prefers a field to be the best alternative besides a garden for cultivating pisang sobo, although, the treatment is less intensive due to temporary use of land.

The distribution of dominant species in field landscape in each village was quite different, as seen from the IVI. The field in Kemiren village was dominated by spinach, pisang sobo, pisang lempeneng, pegagan and rumput pait. In Taman Suruh village, the species that dominated the field were, among others, spinach, pisang sobo, meniran, kemangi, pisang ketip, while in Jambe Sari village the field was dominated by pisang sobo, pisang lempeneng, pisang emas, papaya, and guava. These data indicate that the use of field to build a house or other constructions has lessened the interest of owners in cultivating plants, so the cultivation is less intensive and unplanned. However, the productions from the field still become their main income.

Overall, the plant community structure in four landscape units show the information on the availibity of good food reserve of both fruits and staple food in the three villages that can be utilized by the community. Maintaining the area and the use of four landscape units in the three villages becomes local wisdom in Osing tribe. The mechanism applied in the community is by maintaining good perception towards high self-esteem of paddy field and garden owners, so they rarely sell their paddy fields and gardens.

The vertical stratification and the composition of vegetation in each landscape unit is part of ecological function of the complex integrated house and cultivated plants. Based on the vegetation, each landscape unit has different vertical stratification and species composition (Figure 3).

Except in paddy field landscape unit, the highest stratum (layer) of the yard landscape unit, garden and field, was dominated by hardwood tree species such as durian, petai, coconut, mahagony, jackfruit, and bendo. The middle layer was occupied by many trees and shrubs from many species such as banana, guava, star fruit, mango, and cheese fruit. On the lowest layer, there were mixed herbs and climbing plants such as vegetables, ornamental plants, herbs and spices, medicinal plants; kemangi, spinach, katuk, garden balsam, bougenville, ginger, and screw pine. The highest layer in paddy field landscape unit was occupied by coconuts while the lowest layer was dominated by paddy (Oryza sativa). The complex vertical stratification and diversity of plant species in each landscape unit express the mutual adaptation between human and their environment in local scale (Baiamonte et al. 2015).

Table 4. Plant species with the highest IVI in the garden landscape of the three villages

\begin{tabular}{|c|c|c|c|c|}
\hline \multirow{2}{*}{ Local name } & \multirow{2}{*}{ Scientific name } & \multirow{2}{*}{$\begin{array}{c}\text { Kemiren } \\
\text { IVI } \\
\end{array}$} & \multirow{2}{*}{$\begin{array}{c}\text { Taman Suruh } \\
\text { IVI }\end{array}$} & \multirow{2}{*}{$\begin{array}{c}\text { Jambe Sari } \\
\text { IVI } \\
\end{array}$} \\
\hline & & & & \\
\hline Pisang sobo & Musa $x$ paradisiaca triploid $\mathrm{BBB}$ & 7.02 & 5.71 & 3.93 \\
\hline Bambu benel & Bambusa thouarsii & 6.57 & 2.59 & 5.53 \\
\hline Kelapa & Cocos nucifera & 6.40 & 5.76 & 6.33 \\
\hline Durian & Durio zibethinus & 5.83 & 5.52 & 5.26 \\
\hline Sengon & Albizia chinensi & 5.66 & 3.25 & 2.79 \\
\hline Bambu ori & Bambusa arundinacea & 3.62 & 5.08 & 1.56 \\
\hline Langsat & Lansium domesticum & 4.18 & 4.39 & 4.17 \\
\hline Pisang lempeneng & Musa x paradisiaca triploid AAB & 5.20 & 4.35 & 5.90 \\
\hline Nangka & Artocarpus heterophyllus & 2.88 & 2.49 & 4.73 \\
\hline
\end{tabular}

Table 5. Plant species with the highest IVI in the field landscape of the three villages

\begin{tabular}{|c|c|c|c|c|}
\hline Local name & Scientific name & $\begin{array}{c}\text { Kemiren } \\
\text { IVI }\end{array}$ & $\begin{array}{c}\text { Taman Suruh } \\
\text { IVI }\end{array}$ & $\frac{\text { Jambe Sari }}{\text { IVI }}$ \\
\hline Bayam & Amaranthus gracilis & 7.51 & 5.88 & 5.11 \\
\hline Pisang sobo & Musa x paradisiaca triploid $\mathrm{BBB}$ & 6.72 & 7.79 & 8.47 \\
\hline Pisang lempeneng & Musa x paradisiaca triploid $\mathrm{AAB}$ & 6.40 & 5.65 & 6.37 \\
\hline Pegagan & Centella asiatica & 6.40 & 5.15 & 0 \\
\hline Rumput pait & Axonopus compressus & 6.31 & 0 & 3.85 \\
\hline Meniran & Phyllanthus urinaria & 5.52 & 5.88 & 6.37 \\
\hline Kemangi & Ocimum basilicum & 4.67 & 5.74 & 4.28 \\
\hline Pisang ketip & Musa acuminata & 5.27 & 5.69 & 5.49 \\
\hline Pisang emas & Musa acuminata diploid AA & 5.55 & 4.55 & 7.88 \\
\hline Pepaya & Carica papaya & 4.98 & 4.55 & 7.29 \\
\hline Jambu biji & Psidium guajava & 4.98 & 4.32 & 7.00 \\
\hline
\end{tabular}




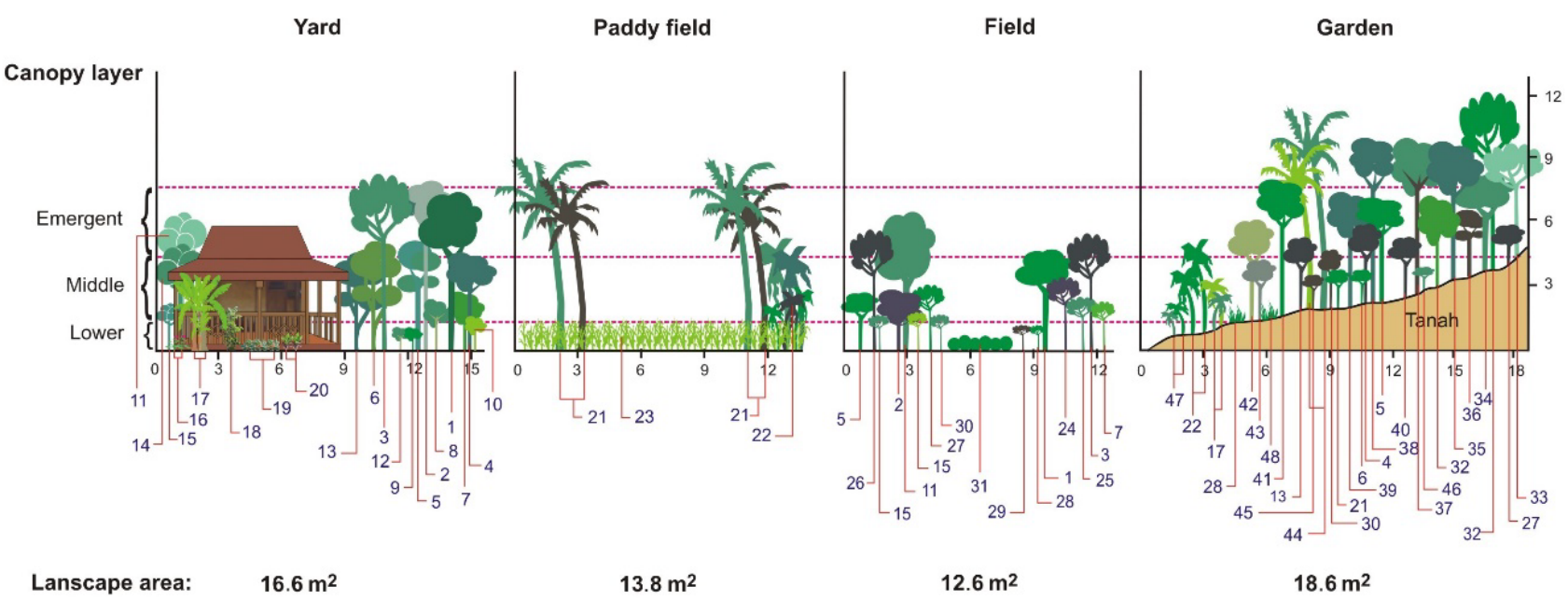

Figure 3. Schematic diagram of vegetation profile on each landscape unit from representative sample research plots

Description of figure

1. Mangifera indica

2. Pterocarpus indicus

3. Nephelium lappaceum

4. Psidium guajava

5. Annona muricata

6. Averrhoa carambola

7. Manilkara kauki

8. Morinda citrifolia

9. Pleomele fragrans

10. Moringa oleifera

11. Parkia harbesonii

12. Cordyline terminalis
13. Syzygium aqueum

14. Sesbania grandiflora

15. Citrus aurantium

16. Rosa sp.

17. Musa acuminata

18. Melastoma affine

19. Aglaonema pictum

20. Codiaeum variegatum

21. Cocos nucifera

22. Musa paradisiaca

23. Oryza sativa

24. Gnetum gnemon
25. Morinda citrifolia

26. Artocarpus heterophyllus

27. Leucaena leucocephala

28. Ocimum basilicum

29. Solanum melongena

30. Aalius androgyna

31. Amaranthus gracilis

32. Durio zibethinus

33. Swietenia mahagoni

34. Artocarpus elasticus

35. Cananga odorata

36. Garcinia mangostana
37. Albizia chinensis

38. Artocarpus camansi

39. Baccaurea racemosa

40. Lansium domesticum

41. Pithecellobium lobatum

42. Cynometra cauliflora

43. Syzygium cumini

44. Averrhoa bilimbi

45. Moringa oleifera

46. Syzygium malaccense

47. Carica papaya

48. Cymbopogon citratus

\section{Gender perception of Osing community towards the environmental values}

Like any other agrarian communities in villages, Osing community still follows the rules on sharing family responsibility between men and women. In general, women stay at home. Osing women in organizational structure of society are positioned as management controller of family, so the development of platform of food security in villages depends on women (Garrity 2004). Based on the position, Osing women gave higher importance value (PDM 45.09) on house with yard than men $(\mathrm{PDM}=40.55)$. Having different role, task, and responsibility, men have to make effort to provide family welfare; therefore, males' perception on paddy field landscape unit was higher $(\mathrm{PDM}=28.47)$ than that of females (PDM=23.63). Paddy field became an important choice for males since the paddy field is the source to food staple and followed by garden and field (Table 6).

Both males and females value paddy field as the second most valuable landscape unit after yard. It shows that paddy field becomes important part in daily lives of Osing tribe in Kemiren, Taman Suruh, and Jambe Sari since it produces staple food. The benefit of paddy field landscape in males' perception was higher than in females' (Table 6).
Table 6. The assessment result of PDM towards landscape unit in gender perspective in Osing tribe community in villages of Kemiren, Taman Suruh, and Jambe Sari

\begin{tabular}{lcc}
\hline Landscape unit & Male & Female \\
\hline Yard & 40.55 & 45.09 \\
Paddy field & 28.47 & 23.63 \\
Garden & 15.84 & 16.40 \\
Field & 15.14 & 14.88 \\
\hline
\end{tabular}

The result shows that males have big responsibility for providing food for their family. They also plant several economically valuable plant species in paddy field as additional source of income.

The the third and fourth beneficial landscapes were garden and field. According to the perception of female, the utilitarian value of the garden was higher than that of field, while the male had the opposite perception (Table 6). It may happen because the benefit assessment of both landscape units is to complete main needs while the main needs are fulfilled by yard and paddy field. Both male and female Osing community meet their economic necessity by using agricultural produce gained from paddy field, yard, and garden. Various plant species have economical value and support family income and become the source of additional income for Osing society. 
The ethnoecology study of Osing tribe in the villages of Kemiren, Taman Suruh, and Jambe Sari, proves that there are ecological process which form the landscapes with their typical vegetation. Osing tribe recognizes four landscape units, namely yard with a house, paddy field, garden, and field. Each landscape unit has important value in the community's life.

\section{ACKNOWLEDGEMENTS}

This study was financed by Institute for Research and Community Service, Open University to which the authors are highly indebted.

\section{REFERENCES}

Agnoletti M, Rotherham ID. 2015. Lanscape and biocultural diversity. Biodiv Conserv 24 (3): 3155-3165.

Baiamonte G, Domina G, Raimondo FM, Bazan G. 2015. Agricultural lanscapes and biodiversity conservation: a case study in sicily (Italy). Biodiv Conserv 24 (3): 3201-3211.

Bakosutarnal. 2006. Peta Citra Desa Lokasi Penelitian, Kabupaten Banyuwangi. Bogor. Peta Rupabumi skala 1:25.000, No Lembar. 1707-414.423. [Indonesian]

Boissiere M, Liswanti N, Padmanaba M, Sheil D. 2007. People Priorities and Perceptions. Towards conservation partnership in Mamberamo. Center for International Forestry Research, Bogor.

Cox GW. 2002. General Ecology, Laboratory Manual. McGraw-Hill Companies, Inc. New York, USA.

Dale VH, Brown S, Haeuber RA, Hobbs NT, Huntly N, Naiman RJ, Riebsame WE, Turner MG, Valone TJ. 2000. Ecological principles and guidelines for managing the use of land. Ecol Appl 10 (3): 639670 .

Dolisha F, Mc Daniel JM, Teeter LD. 2007. Farmer's perceptions towards forests: A case study from Haiti. For Pol Econ 9: 704-712.

Farina A. 2000. The cultural landscape as a model for the integration of ecology and economics. BioScience 50 (4): 313-320.

Fischer J, Hartel T, Kuemmerle T. 2012. Conservation policy in traditional farming landscapes. Conservation Letters 5 (3): 1-9.
Gadgil M, Berkes F, Folke C. 1993. Indigenous knowledge for biodiversity conservation. AMBIO 22 (2-3): 151-156.

Garrity DP. 2004. Agroforestry and the achievement of the Millennium Development Goals. Agroforestry Systems 61: 5-17.

Guthiga PM. 2008. Understanding Local Communities Perceptions Of Existing Forest Management Regimes Of A Kenyan Rainforest, Jurnal Kenya 4: 246-250.

Hapsari L, Lestari DA, Masrum A. 2015. Album Koleksi Pisang (Musaceae) Kebun Raya Purwodadi Seri 1: 2010-2015. Unit Pelaksana Teknis Balai Konservasi Tumbuhan Kebun Raya Purwodadi, LIPI. Pasuruan. Jawa Timur. [Indonesian]

Kennedy. 2009. Bananas and People in The Homeland of Genus Musa: not just pretty fruit. Ethnobot Res Appl 7: 179-197.

Neuman WL. 2003. Social Research Methods Qualitative and Quantitative Approaches ( $5^{\text {th }}$ eds.). Allyn and Bacon, USA.

Olwig KR. 1996. Recovering the Substantive Nature of Lanscape. Ann Assoc Amer Geogr 86 (4): 630-653.

Rao MR, Palada MC, Becker BN. 2004. Medicinal and aromatic plants in agroforestry systems. Agroforestry Systems 61: 107-122.

Raynor B, Kostka M. 2003. Back to future: Using traditional knowledge to strengthen biodiversity conservation in Pohnpei, Federated States of Micronesia. Ethnobot Res Appl 1: 55-63.

Rosa M, Orey DC. 2012. The field of research in ethnomodeling: emic, ethic and dialectical approaches. Educ Pesqul Sao Paulo 38 (4): 865879.

Schaich H. 2009. Local residents' perceptions of floodplain restoration measures in Luxembourg's Syr Valley. Landsc Urb Plan 93: 20-30.

Sheil D, Puri RK, Basuki I, van Heist M, Wan M, Liswanti N, Rukmiyati, Sardjono MA, Samsoedin I, Sidiyasa K. et al. 2002. Eksploring biological diversity, environment and local people's perspectives in forest lanscapes: Methods for a multidisciplinary assessment. Center for International Forestry Research, Bogor.

Sutarto A. 2006. Sekilas Tentang Masyarakat Using. Makalah Seminar Kegiatan Jelajah Budaya tahun 2006. Balai Kajian Sejarah dan Nilai Tradisional. Yogyakarta. [Indonesian]

Tardio G, Stokes A, Mickovski SB, Devkota S. 2017. Bamboo structures as a resilient erosion control measure. ICE Proceeding 170 (2): 1-12.

Vodouhe F, Coulibaly O, Adegbidi A, Sinsin B. 2010. Community perception of biodiversity conservation within protected areas in Benin. For Pol Econ 12: 505-512.

White Jr.TH, Camacho AJ, Bloom T, Diéguez PL, Sellares R. 2011. Human perceptions regarding endangered species conservation: a case study of Saona Island, Dominican Republic. Latin Amer J Conserv 2 (1): 18-29. 